\title{
MAIN CHARACTERISTICS TO DISTINGUISH BACTERICERA COCKERELLI FROM OTHER PSYLLIDS IN NEW ZEALAND
}

\author{
P.J. DALE ${ }^{1}$ and M-C. NIELSEN ${ }^{2}$ \\ ${ }^{1} 401$ Hillsborough Road, Mt. Roskill, Auckland, New Zealand \\ ${ }^{2}$ The New Zealand Institute for Plant \& Food Research Limited, Private Bag \\ 4704, Christchurch, New Zealand \\ Corresponding author: nielsenm@crop.cri.co.nz
}

The tomato/potato psyllid, Bactericera cockerelli (Sulc) (Hemiptera: Triozidae), is found throughout most of New Zealand along with a range of native and other introduced psyllids all belonging to the superfamily Psylloidea. The Psylloidea contains six families of which four are recorded from New Zealand (Psyllidae, Calophyidae, Homotomidae and Triozidae). Species belonging to Triozidae have trifurcate branching on the basal vein of the forewing in contrast to the other psyllid families in New Zealand, which have bifurcate branching. Bactericera cockerelli can be distinguished from other Triozidae species by the number of inner apical spurs on the tibiae of the hind legs (2), size and shape of the cubital cell in the forewing (short and compact), absence of long setae on vertex and dorsal thoracic surfaces, and the lack of well developed genal cones. Illustrations of these characters can be seen on insectwatch.com. Usually body markings in insects are not suitable for identification purposes since these are likely to vary. However, the very distinct markings (white marginal and inner patch) on the vertex (dorsal surface of head) of $B$. cockerelli seem stable and are a very useful characteristic for distinguishing this species from other psyllids in New Zealand.

\section{REDUCING RATE OF AUSTRALIAN EUCALYPTUS INSECTS INVADING NEW ZEALAND}

\author{
T.M. WITHERS and J. BAIN
}

Forest Biosecurity and Protection, Scion, PB 3020, Rotorua 3046, New Zealand

Corresponding author: toni.withers@scionresearch.com

Trees in the introduced genus Eucalyptus form an important part of New Zealand's flora. Since the 1860s, Australian insects have steadily colonised this resource in this novel habitat. There are now 28 specialist eucalypt insect species and approximately another 30 more polyphagous insect species that may feed on Eucalyptus spp., established in New Zealand. Throughout the 1990s the rate at which these insects had invaded New Zealand reached a peak of one insect every 18 months. This study shows how the invasion rate appears to have dropped to one insect every five years. Since 2000, only two new eucalyptus pests have established, both being psyllids first identified in 2002, Creiis liturata (Froggatt) and Anoeconeossa communis Taylor. The eucalypt-specific insect invaders are now dominated by sap-sucking bugs, particularly psyllids. It may be that this group of insects is being dispersed the $1800 \mathrm{~km}$ by aerial flight, a natural pathway that will not be able to be closed. 